\title{
How Do Managers Control Technology-Intensive Work?
}

\author{
Angelo Bernard Pinheiro'
}

\begin{abstract}
Technology pervades every aspect of the modern business enterprise and demands new strategies for work management. Advances in internet and computing technologies, the emergence of the "knowledge worker", globalization, resource scarcity, and intense competition have led corporations to accomplish their strategic goals and objectives through the implementation of projects. Project success is assured by the effective use of financial and human resources, a project management (PM) framework backed by senior management, and controls spanning the PM spectrum of initiation; planning; implementation; monitoring, measurement, and control; and closing. As an essential function of management, 'control' may be accomplished through a PM Plan, a project-matrix organization, competent and motivated people, and appropriate management tools and techniques. A PM Plan conforming to the Project Management Body of Knowledge (PMBOK) framework incorporates controls for the key PM elements and, implemented properly, can assure project success.
\end{abstract}

Keywords: project management; control; self-directed teams; project-matrix organization; PMBOK; earned value analysis, project risk assessment; schedule compression analysis; quality function deployment; management tools.

\footnotetext{
I MS Program in Technology Management. College of Business \& Technology. Department of Industrial Engineering \& Technology. Texas A\&M University-Commerce. Commerce, TX 75429-30 I I. Tel: (7I3) 296-3820. Fax: (7I3) 296-340I.

E-mail: apinheiro@leo.tamu-commerce.edu
} 


\section{Introduction}

Control is an essential function of management and it facilitates the accomplishment of the organization's goals and objectives. Managers in technology-intensive organizations use controls to accomplish strategic goals and objectives amid rapidly changing technology, globalization, scarcity of resources, end-date driven schedules, increasing regulations, disruption, and risk (Drucker, 2000; Thamhain, 1994). Managers also shoulder responsibility for orchestrating and optimizing the use of technology, human and financial resources, systems, and the environment in which the work will be performed. Research shows that both large corporations and Small and Medium Enterprises (SME) that use technology to influence work outcomes have a greater likelihood of success when the work is managed as projects (Murphy and Ledwith, 2007; Anantamula, 2008; Bradshaw, 2008). However, projects can fail if not properly planned, controlled and managed. The reasons for failure include but are not limited to: multi-nodality, where PM focuses on core areas to the detriment of outlying areas in spatially distributed organizations; organizational slack, where the lack of resources in a particular area affects the functioning of the project; lack of top-down and bottom-up interventions; insufficient buy-in from the project team; project managers who also are business managers; unclear project plans; ambiguous roles and responsibilities; team member burnout; inefficient management of change; and poor organizational culture (Ivory, Alderman, 2005; Bahel, 2009).

The management of technology-intensive work therefore calls for projects to be managed formally under a PM framework that includes a PM Plan, project organization, PM tools and techniques, and performance monitoring, measurement, and control. As "people" represent the other critical dimension of PM, project managers must have the ability to organize, motivate, lead, and harness the individual and collective knowledge and skills of their human resources (PMI, 2008).

This paper discusses the factors that influence managerial control of technology-intensive work and the tools and techniques available to the Project Manager. Due to the vast body of literature on PM, managerial control is discussed in the context of a PM framework, people, organizational design, and PM tools and techniques.

\section{Managerial Control in Project Organizations}

Managerial control is accomplished through a PM Plan, measuring performance, taking corrective action, and feeding back performance results and data for continuous improvement of the plan, personnel, and project scope or configuration.

\section{Project Management Framework}

Project controls are often dictated by numerous and increasingly stringent legislation, corporate social responsibility policies, and industry-accepted management practices. The accountability of owners and company directors to regulators, investors, and other stakeholders further influence the strength of internal management controls (Bradshaw, 2008). Senior management therefore has a special interest in ensuring that projects are managed in a manner such that potential liability from damage or loss of reputation is minimized.

Management commitment is a key ingredient of project success and it should be leveraged for controlling the development and implementation of policies; approval of the PM Plan; initial and additional financial and non-financial resources; approval of changes to the project scope, project documentation, organizational assets, and the PM Plan; procurement of PM tools and software; approval of residual risks; influencing the outcomes of pending legislation, and so forth.

A PM Plan provides the framework and mechanism for project control. A globally-accepted model PM framework is the Project Management Institute's (PMI) Project Management Body of Knowledge (PMBOK). The PMBOK Guide (2008) includes 42 management processes under nine knowledge areas which logically correlate to five project phases. The knowledge areas are: project integration management, project scope management, project time management, project quality management, project human resource (HR) management, project communications management, project risk management, and project procurement management. The relationship between these knowledge areas is such that changes in one 
element produce a corresponding change in at least one other element. When that happens, control must be exercised to counteract the deviation to keep the project on track. For example, if project costs escalate, changes may be needed to the scope (for example, changes to product design) and procurement process (for example, change in suppliers or strengthening of contractual terms). The five project phases represent: initiation, planning, executing, management and control, and closing (PMI, 2008). These overlap to some extent and the monitoring and control process cuts across all phases.
The PMBOK model defines controls for all but the Project HR Management element. HR controls are accomplished through personnel selection, teaming, motivation, and performance appraisal. Figure I illustrates a practical application of PMBOK by the Naval Space and Warfare Center, CA. Table I depicts the PMBOK model.

An alternative PM framework model, focused around "project controls" was developed by Bradshaw (2008) and is illustrated in figure 2.

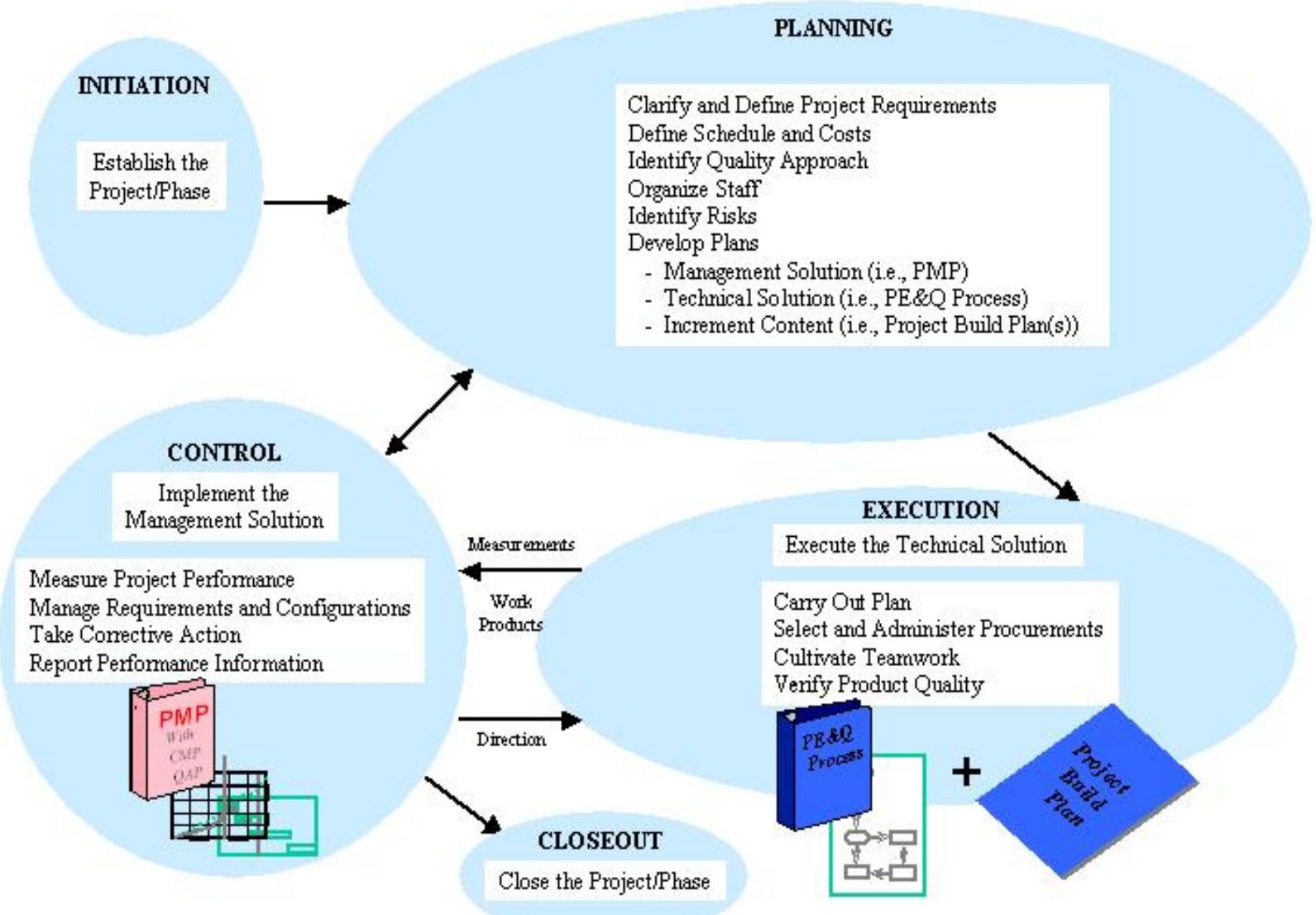

Figure I. Typical Project Management Framework. Reproduced from Project Management Plan Template, Naval Space \& Warfare Center, San Diego, CA. 


\begin{tabular}{|c|c|c|c|c|c|}
\hline \multirow[b]{2}{*}{$\begin{array}{l}\text { Knowledge } \\
\text { Areas }\end{array}$} & \multicolumn{5}{|c|}{ Project Management Process Groups } \\
\hline & Initiating & Planning & Executing & $\begin{array}{l}\text { Monitoring \& } \\
\text { Control }\end{array}$ & Closing \\
\hline $\begin{array}{l}\text { Project } \\
\text { Integration } \\
\text { Management }\end{array}$ & $\begin{array}{l}\text { - Develop } \\
\text { Project } \\
\text { Charter }\end{array}$ & - Develop PM Plan & $\begin{array}{l}\text { - Direct and } \\
\text { Manage Project } \\
\text { Execution }\end{array}$ & $\begin{array}{l}\text { - Monitor and } \\
\text { Control Project } \\
\text { Work } \\
\text { - Perform } \\
\text { Integration and } \\
\text { Change Control }\end{array}$ & $\begin{array}{l}\text { - Close } \\
\text { Project or } \\
\text { Phase }\end{array}$ \\
\hline $\begin{array}{l}\text { Project } \\
\text { Scope } \\
\text { Management }\end{array}$ & & $\begin{array}{l}\text { - Collect } \\
\text { Requirements } \\
\text { - Define Scope } \\
\text { - Create WBS }\end{array}$ & & $\begin{array}{l}\text { - Verify Scope } \\
\text { - Control Scope }\end{array}$ & \\
\hline $\begin{array}{l}\text { Project Time } \\
\text { Management }\end{array}$ & & $\begin{array}{l}\text { - Define Activities } \\
\text { - Sequence Activities } \\
\text { - Estimate Activity } \\
\quad \text { Resources } \\
\text { - Estimate Activity } \\
\quad \text { Duration } \\
\text { - Develop Schedule }\end{array}$ & & $\begin{array}{l}\text { - Control } \\
\text { Schedule }\end{array}$ & \\
\hline $\begin{array}{l}\text { Project Cost } \\
\text { Management }\end{array}$ & & $\begin{array}{l}\text { - Estimate Costs } \\
\text { - Determine Budget }\end{array}$ & & - Control Costs & \\
\hline $\begin{array}{l}\text { Project } \\
\text { Quality } \\
\text { Management }\end{array}$ & & - Plan Quality & - Perform QA & $\begin{array}{l}\text { - Perform Quality } \\
\text { Control }\end{array}$ & \\
\hline $\begin{array}{l}\text { Project } \\
\text { Human } \\
\text { Resource } \\
\text { Management }\end{array}$ & & $\begin{array}{l}\text { - Develop Human } \\
\text { Resource Plan }\end{array}$ & $\begin{array}{l}\text { - Acquire Project } \\
\text { Team } \\
\text { - Develop Project } \\
\text { Team } \\
\text { - Manage Project } \\
\text { Team }\end{array}$ & & \\
\hline $\begin{array}{l}\text { Project } \\
\text { Communicati } \\
\text { ons } \\
\text { Management }\end{array}$ & $\begin{array}{l}\text { - Identify } \\
\text { Stakeholders }\end{array}$ & $\begin{array}{l}\text { - Plan } \\
\text { Communications }\end{array}$ & $\begin{array}{l}\text { - Distribute } \\
\text { Information } \\
\text { - Manage } \\
\text { Stakeholder } \\
\text { Expectations } \\
\end{array}$ & $\begin{array}{l}\text { - Report } \\
\text { Performance }\end{array}$ & \\
\hline $\begin{array}{l}\text { Project Risk } \\
\text { Management }\end{array}$ & & $\begin{array}{l}\text { - Plan Risk } \\
\text { Management } \\
\text { - Identify Risks } \\
\text { - Perform Qualitative } \\
\text { Risk Analysis } \\
\text { - Perform } \\
\quad \text { Quantitative Risk } \\
\text { Analysis } \\
\text { - Plan Risk Responses }\end{array}$ & & $\begin{array}{l}\text { - Monitor and } \\
\text { Control Risks }\end{array}$ & \\
\hline $\begin{array}{l}\text { Project } \\
\text { Procurement } \\
\text { Management }\end{array}$ & & - Plan Procurements & $\begin{array}{l}\text { - Conduct } \\
\text { Procurements }\end{array}$ & $\begin{array}{l}\text { - Monitor } \\
\text { Procurements }\end{array}$ & $\begin{array}{l}\text { - Close } \\
\text { Procureme } \\
\text { nts }\end{array}$ \\
\hline
\end{tabular}

Table I. Project Management Body of Knowledge (PMBOK). Reproduced from "A Guide to the Project Management Body of Knowledge”, $4^{\text {th }}$ Ed., PMI, Newton Square, MA 


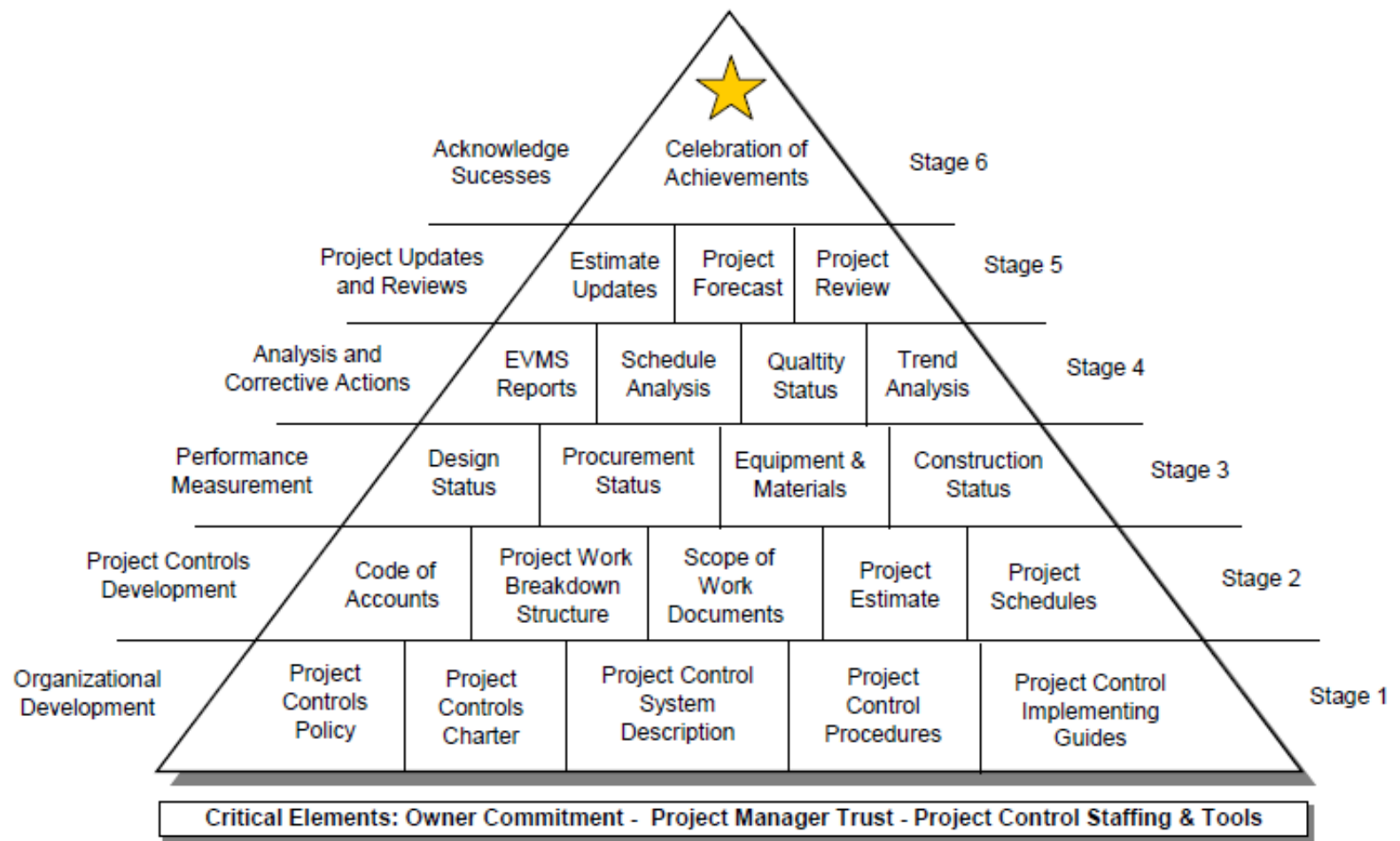

Figure 2. Bradshaw's Pyramid Model of Project Controls Execution. Reproduced from "Establishing a First Class Project Controls Organization for Managing Large Complex Projects” by G.B. Bradshaw (2008).

\section{People}

People are the most critical aspect of PM and the channel through which work controls are initiated, implemented and managed (Bradshaw, 2008). Bradshaw identified owner commitment, Project Manager trust, and staffing as critical elements for project success. His 6-stage Pyramid Model depicts people as the common denominator for project execution, with Stage 6 reserved exclusively for celebrating accomplishments upon project completion.

Project team members must possess not only the desired qualifications, skills, and experience for the job, but also have personality traits and work ethics that are compatible with the organization's values and culture (Brenner, 2007). Today's "knowledge workers" expect autonomy, continuous learning, and innovation to be part of the job, task or responsibility (Drucker, 1999). They are better educated than their counterparts in the past, and function well in self-directed, high performance teams. Team design is therefore an important managerial control. It facilitates the functioning of self-directed teams and improves the quality of member relationships and satisfaction (Wageman, 200I). Decision-making authority, responsibilities, and accountabilities of team members should be clearly defined in order to eliminate role ambiguity and inter-departmental conflicts (Possner, Randolph, 1979; Bradshaw, 2008). Involving teams in the early stages of project planning promotes integrated team building (Thomas et al, 2008), buy-in and project ownership.

Once the project teams have assembled and settled down, they should be coached and supported in fulfilling their roles. Mentoring, empowerment, and motivation are powerful, albeit indirect controls of project success as they bring out the best in individual and project team performance (Wageman, 200I; Pryor et al, 2007). Mentoring fosters social break-in, strengthens organizational commitment, and reduces turnover (Payne, Huffman, 2005). Empowerment vests authority for decision-making in individuals and self-directed teams, and 
it can be a powerful tool for project success. Motivation is a key influencer of behavior and it helps maintain a high level of commitment to project goals. Motivators, such as performance recognition and reward, opportunities for training and professional development, comfortable work environment, challenging work, workplace policies, involvement in decision-making, and so forth, represent useful controls to the Project Manager (Brenner, 2007; Pryor et al, 2007). Motivational concepts are essential to good management and an understanding of the application and use of motivational theories, such as Maslow's Hierarchy of Needs, McGregor's Theory X \&Y, Herzberg's Motivation-Hygiene (Two-Factor) Theory, Vroom's Performance Expectation Theory, Skinner's Behavior Modification/Reinforcement Theory, and Mayo's Hawthorne Effect, immensely benefits the Project Manger (Pryor et al, 2007).

Anxieties and threats should be anticipated and conflicts managed through open communication, observations and conversations, conflict management, the issues log, and interpersonal skills (PMI, 2008). Today's knowledge workers are self-directed and thrive on challenges. Project Managers create and control such work environments by understanding the strengths and limitations of their employees and providing them with work assignments that encourage creativity and innovation.

Finally, performance appraisals are a key measurement of accountability, commitment, self direction and control, and they help in correcting deviations from expected performance norms. Performance is measured against project standards, job descriptions, team deliverables, project schedules, cost schedules, and so forth (Bradshaw, 2008; PMI, 2008).

\section{Organizational Design}

Organizational design plays a key role in controlling technology intensive work. Organizational design considerations include: the nature of the product or service, the temporal and spatial distribution of work locations, in-house versus outsourcing of the work, the flexibility and convenience afforded by "virtual organizations", concurrent engineering and integrated product development, the extent of technology use, the availability of core competencies, and strategic objectives of the organization.
Advances in information and communication technology have led to the emergence of the virtual organization and greater outsourcing of work. Inexpensive, skilled labor in developing nations provides incentives to corporations to conduct part or entire projects abroad. For example, the construction of an oil and gas production platform may involve fabrication of the hull in Abu Dhabi, topside in Italy, engineering design in India, and final assembly in the U.S. These jobs are distinct components (or sub-projects) of the project and may be executed by multiple contractors that are managed and controlled by the project proponent.

Globalization and international trade agreements have resulted in $\mathrm{N}$. American companies forming joint ventures and/or opening overseas manufacturing bases. An organization may have several operating locations within its home country. The challenges of managing spatially and temporally dispersed business units underline the importance of organizational design as a managerial control. Furthermore, the transition from a manufacturing to a service-based economy, and the emergence of the "knowledge worker", dictates that organizational design be suitable for deliverables such as time to market, quality, cost, schedule, and so on.

Organizations have responded to the above-mentioned changes by transitioning from functional hierarchies to cross-functional teams, integrated product development teams, and project teams. (Pryor et al, 2007). Cooperation between team members is improved significantly when the goals are clear, project team rules and procedures are defined, and the work is performed in physical proximity (Pinto et al, 1993). These factors are controllable by the Project Manager and indirectly, but positively, influence task perception and psychosocial outcomes (Pinto et al, 1993).

A cross-functional, project-matrix style organization is suitable for high technology work (Pryor et al, 2007). As a managerial control, it: a) enables top down and lateral communications by interconnecting people, activities, and support functions, b) facilitates concurrent engineering and integrated product development, c) reduces decision making and response time, d) allows disengagement of team members and their redeployment to other projects, e) provides employees opportunities for self-development through cross- 
functional exposure, thereby increasing motivation and job satisfaction, $f$ maximizes the use of human resources by tapping into the organizational knowledge base, g) reduces time to market, and, h) promotes innovation and technical excellence (Ford, Randolph, 1992).

Matrix organizations also pose managerial control challenges with respect to sharing of power and resources; employee performance evaluation; remuneration and promotion; conflict between functional and project managers; the time required to meld personnel into effective teams; cost allocation; and nonproductive time attending meetings (Ford, Randolph 1992; Pryor et al, 2007). These challenges are counteracted by increasing interdepartmental information flow, involving people in decision making, and promoting teamwork (Posner B., Randolph, A., 1979).

\section{Project Control Tools and Techniques}

Project control tools and techniques represent the means and mechanism by which Managers monitor, measure, and manage the work deliverables. Traditionally, projects have been tracked for budget, schedule, and deliverables. The level of control was basic, but considered adequate for centralized, functional-style organizations operating in static, production-oriented environments. Today's work environment is more complex and contemporary management practices dictate that PM techniques and tools be capable of solving complex problems, facilitating effective control of work deliverables, and contributing to continuous improvement (Pryor et al, 2007). Furthermore, PM tools should not only fulfill their intended purpose, but also be user friendly, compatible with organizational culture, and in alignment with business processes. Pretesting new tools in the environment they will be used, soliciting feedback from users, and "fixing" incompatibilities, smoothens the introduction of the new tool into the workplace.

PM control techniques may be categorized as analytical management, process-oriented, or people-oriented. The discussion that follows correlates popular PM techniques with the 'monitoring and control' aspect of PMBOK for each project knowledge area, and as depicted in Table 2. This is not an exhaustive list, by any means, as several tools and techniques are available for the Project Manager to choose from. Some of those find application in multiple knowledge areas. Select project control tools and techniques are discussed below.

\section{Computer Software}

Numerous software applications are available for PM, and when integrated with business processes, they enable better project tracking and control. PM software utilization is greater when: the need for information quality is high, the project is more complicated, and the software provides greater functionality (Ali et al, 2008). Software should be user-friendly, compatible with current and future planned upgrades of the organization's Information Technology (IT) system, backed by round-the-clock customer support, and protected against data corruption and unauthorized access. The project team should be trained on the software to increase their familiarity and use of the same. Popular PM software applications include Microsoft Project, Primavera, Open Plan, Artemis, and Project Workbench (Ali et al, 2008).

\section{Benchmarking}

Benchmarking involves "comparing actual or planned project practices to those of comparable projects to identify best practices, generate ideas for improvement, and provide a basis for measuring performance" (PMI, 2008). Benchmarking helps organizations know their strengths and weaknesses compared to the competition and 'best in class' standards. It enables the establishment of controls that trigger corrective action. Benchmarks are an important tool for independently verifying estimates and schedules (Bradshaw, 2008), for example, when bids are received for major projects.

Performance benchmarks are used by project managers for comparing and tracking parameters such as 'time to market', major milestones, safety accident rates, greenhouse gas emissions, cost of production/unit, and customer satisfaction. Benchmarks are selected prudently in order to be relevant (apples compared to apples) and produce real improvement. That requires knowing who and what to benchmark, collecting and analyzing data to identify "best in class", evaluating strategies, operations, and processes against the benchmarks, setting improvement targets, and corrective action when 
performance drops below the benchmark (Pryor et al, 2007).

\section{Earned Value Analysis (EVA)}

EVA integrates project cost and scheduling and provides a comparison of project completion status to the budgeted expenditure. It requires, as inputs, a) a task list, b) scheduled start and end dates for each tasks, c) anticipated labor hours for each task, d) actual costs incurred on each task, and e) percentage completed for each task in the task list. As outputs, EVA produces: a) the actual cost of work performed, b) the budgeted cost of work performed, c) budgeted cost of work scheduled, d) the schedule variance, and e) the cost variance
(Cesarone, 2007). EVA provides an early warning of potential problems and is used to improve the forecast of estimate of completion (Bradshaw, 2008).

\section{Quality Function Deployment (QFD)}

QFD, also known as the "Voice of the Customer" and "House of Quality", is a process-oriented project control. It is a facilitated approach that helps in determining the critical characteristics of new product development, and it works by collecting, sorting and prioritizing customer needs and setting goals to achieve them (PMI, 2008). QFD shows how a change in one engineering characteristic affects other characteristics of the product (Pryor et al, 2007).

\begin{tabular}{|c|c|c|}
\hline PMBOK Knowledge Area & $\begin{array}{l}\text { PMBOK Monitoring \& } \\
\text { Control Requirements }\end{array}$ & Management Tools and Techniques \\
\hline Project Integration Management & $\begin{array}{l}\text { - Monitor and Control } \\
\text { Project Work } \\
\text { - Perform Integrated } \\
\text { Change Control }\end{array}$ & $\begin{array}{l}\text { - Requirements Analysis } \\
\text { - Computer Software } \\
\text { - Simulation } \\
\text { - Out-of-Bounds Review } \\
\text { - Benchmarking } \\
\text { - Management of Change Process }\end{array}$ \\
\hline Project Scope Management & $\begin{array}{l}\text { - Verify Scope } \\
\text { - Control Scope }\end{array}$ & $\begin{array}{l}\text { - Project Definition } \\
\text { - Design Review } \\
\text { - Prototyping } \\
\text { - Status Assessment } \\
\text { - Deficiency Report }\end{array}$ \\
\hline Project Time Management & - Control Schedule & $\begin{array}{l}\text { - Concurrent Engineering } \\
\text { - PERT/CPM } \\
\text { - Schedule Compression Analysis } \\
\text { - Schedule Tracking } \\
\text { - Stage-Gate Review }\end{array}$ \\
\hline Project Cost Management & - Control Costs & $\begin{array}{l}\text { - Budget Tracking } \\
\text { - Earned Value Analysis } \\
\text { - Variance Analysis }\end{array}$ \\
\hline Project Quality Management & - Perform Quality Control & $\begin{array}{l}\text { - Quality Function Deployment } \\
\text { - Voice of the Customer }\end{array}$ \\
\hline Project HR Management & & $\begin{array}{l}\text { - Core Team } \\
\text { - Focus Group } \\
\text { - Joint Performance Evaluation } \\
\text { - Self-Directed Team }\end{array}$ \\
\hline Project Communications Management & - Report Performance & $\begin{array}{l}\text { - Interface Chart } \\
\text { - Action Item/Report }\end{array}$ \\
\hline Project Risk Management & $\begin{array}{l}\text { - Monitor and Control } \\
\text { Risks }\end{array}$ & $\begin{array}{l}\text { - Qualitative Risk Assessment } \\
\text { - Quantitative Risk Assessment }\end{array}$ \\
\hline
\end{tabular}




\begin{tabular}{|c|c|c|}
\hline & & $\begin{array}{l}\text { Economic } \\
\text { - Net Present Value Methods } \\
\text { - Rate of Return Methods } \\
\text { - Ratio Methods } \\
\text { - Payback Methods } \\
\text { - Accounting Methods } \\
\text { Health, Safety \& Environmental } \\
\text { - Project Risk Assessment } \\
\text { - Failure Modes and Effects Analysis } \\
\text { - Hazard and Operability Studies } \\
\text { - Fault Tree Analysis } \\
\text { - Safe Work Permitting }\end{array}$ \\
\hline Project Procurement Management & - Administer Procurements & $\begin{array}{l}\text { - Contract Change Control System } \\
\text { - Bids Analysis and Ranking } \\
\text { - Procurement Performance Reviews }\end{array}$ \\
\hline
\end{tabular}

Table 2. Project Management Tools \& Techniques

\section{Pre-job Planning/Project Risk Assessment (PRA)}

Health, safety, and environmental (HSE) risks are inherent in technology-intensive work due to the involvement and interaction of people, multiple contractors, equipment, materials, and the environment. Prudent managers conduct HSE risk assessments before undertaking major projects that involve potentially hazardous activities or situations so that the risks can be identified, evaluated, and controlled. This process involves a multi-disciplinary team review of the hazards associated with key phases of the project or job, their consequences, and the controls in place or required to prevent or mitigate the risks. It provides for residual risk acceptance and authorization, risk communication between workplace parties, and confirmation of completion of the corrective actions. A PRA poster guide is shown in Figure 3 by way of example. The risk assessment is performed using the following steps:

- Gather information and documentation needed for reference, such as the project scope of work, site plans, Piping and Instrumentation Diagrams (P\&ID), Process Flow Diagrams (PFD), standards, processes, etc.

- Divide the job into the major or distinct phases of activity, for example: site preparation, equipment mobilization, operations, demobilization, and site clean-up and restoration.
- Identify the hazards associated with the key work activities, using the PRA guide.

- Identify the potential consequences for each identified hazard, for example: electrocution, fire, spill.

- Identify and rank the existing HES controls as 'High' (in place or easily obtained), 'Medium' (not all desired controls are available), or 'Low' (desired controls are not in place or not easily obtainable).

- Evaluate the Confidence in Implementation for the HES controls in terms of 'High', 'Medium', 'Low', using the PRA poster for guidance.

- Determine the risk ranking using the risk matrix and determine if additional controls are needed to reduce the risk. Consider using higher order HES controls, where practicable.

Assign responsibility and timeline for each corrective action and track corrective actions to closure. 


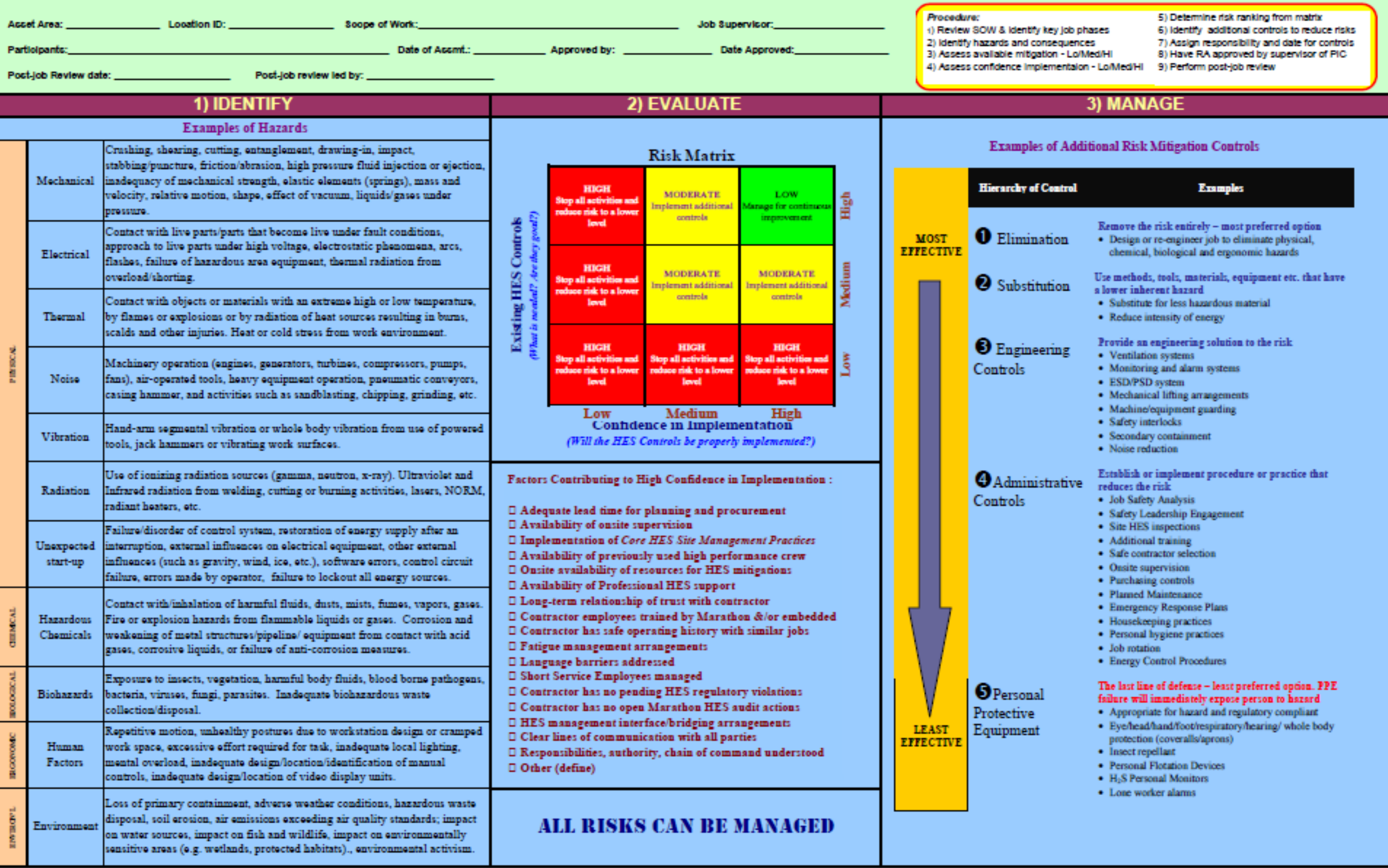

Figure 3. Example of a Project Risk method. 
Schedule Compression Analysis (SCA)

Projects are subject to vagaries of unanticipated cost and schedule overruns due to constraints that often are beyond the Project Manager's control. This results in a slippage of the project milestones. Early completion dates might be dictated or warranted for various reasons, including investor demands, governmental permit requirements, "windows of opportunity", upcoming projects that will use the same personnel and resources, and so on. SCA provides a graphical illustration of how the project duration can be shortened by "crashing" or "fast tracking" without changing the scope (PMI, 2008).

"Crashing" is a schedule compression technique that involves an analysis of project costs and schedules to determine the maximum possible compression, by extending overtime or providing additional resources, for the least incremental cost. It involves additional costs and risks. "Fast Tracking" is a schedule compression technique in which work phases or activities that are normally performed sequentially, can be overlapped so that they are performed in parallel to reduce the completion time. SCA requires accurate cost, time, technical performance data, and the establishment of measurable milestones (PMI, 2008).

\section{Action Item Report}

"Action Items" are the control measures that are taken, when deviations or non-conformities against a reference standard, or project requirement are identified. Action Items are identified through audits, risk assessments, stakeholder meetings, investigations, management of change requests, and so on. Action Items are assigned to project team individuals by name (or job title), and with a 'due date' for completion. They are usually documented in the "Issues Log" and tracked to completion. Management intervention may be needed when those due dates are exceeded without reasonable justification, so that the project is not delayed. The Issues Log also facilitates communication of the pending corrective actions and the responsibility for closure. The successful implementation of Action Items calls for individual commitment, and it may require additional resources.

\section{Conclusion}

Organizations that manage work as projects have a greater likelihood of success in a competitive business environment. Managerial control in project-oriented organizations is accomplished through the implementation of PM plans; prudent HR policies; project-matrix organization structures; and project tools and techniques that are commensurate with the project scope and risks. This article discussed select examples from the vast array of PM plan templates, tools and techniques that are available to the contemporary Project Manager. Those included the PMBOK and Pyramid Model PM plan templates; various PM software; and management techniques including benchmarking, Earned Value Analysis, Quality Function Deployment, Project Risk Assessment, Schedule Compression Analysis, and Action Item Report. Evaluating PM tools and techniques for compatibility with the organization's existing systems and processes and training end users in their correct use will improve the implementation and effectiveness of these controls. The accruing benefits include: improved tracking and control of project costs, schedule, and deliverables; reduced risks and liabilities; ability to meet and potentially exceed quality standards and performance benchmarks; competitive edge; and a better motivated and competent project team.

\section{References}

ALI, A. S., Frank, T, William, H. (2008). Impact of organizational and project factors on acceptance and usage of project management software and perceived project success. Project Management Journal, 39(2), 5-33.

ANANTAMULA, V. S. (2008). The role of technology in the project manager performance model. Project Management Journal, 39(I), 34-48.

BAHEL, J. (2009). Why big IT projects fail. CIO Insight, I03, |4-|4.

BARKLEY, B. (2008). Project management and teamwork. Project Management: New Product Development, 303-323. McGraw Hill Professional, New York.

BRADSHAW, G. B. (2008). Establishing a first class project controls organization for managing large complex projects. AACE International Transactions 2008, I-9. 
BRENNER, D. A. (2007). Achieving a successful project by motivating the project team. Cost Engineering, 49(5), 16-20.

CESARONE, J. (2007). Project management by numbers: How Earned Value Analysis can keep you on track. Industrial Engineer, 39(II), 36-4I.

DRUCKER, P. (1999). Knowledge worker productivity: The biggest challenge. California Management Review, 4 I (2), 79-94.

DRUCKER, P. (2000). Challenges for the $2 \mathrm{I}^{\text {st }}$ century. Tooling \& Production, 66(I), 92-97.

FORD, R. C., Randolph, A. W. (1992). Cross-functional structures: A review and integration of Matrix Organization and Project Management. Journal of Management, 18(2), 267-294.

IVORY, C., Alderman, N. (2005). Can Project Management learn anything from studies of failure in complex systems? Project Management Journal, 65(3), 5-16.

MURPHY, A., Ledwith, A. (2007). Project Management tools and techniques in high-technology SMEs. Management Research News, 30(2), 153-166.

PAYNE, S. C., Huffman, A. H. (2005). A longitudinal examination of the influence of mentoring on organizational commitment and turnover. Academy of Management Journal, 48(I), I58-168.

PINTO, M. B., Pinto, J. K., Prescott, J. E. (1993). Antecedents and consequences of project team crossfunctional cooperation. Management Science, 39(10), 128I1297.

POSNER, B. Z., Randolph, A. W. (1979). Perceived situational moderators of the relationship between role ambiguity, job satisfaction, and effectiveness. Journal of Social Psychology, 109, 237-244.

PMI (2008). A guide to the Project Management Body of Knowledge. PMBOK Guide $-4^{\text {th }}$ Ed. Project Management Institute, Newton Square, MA.

PMI (2009). Project Management Institute: Who we are and what we do. http://www.pmi.org/AboutUs/Pages/ FactSheet.aspx [Accessed November 23, 2009].
PRYOR, M. G., White, C. J., Toombs, L. A. (2007). A strategic systems approach to continuous improvement. Strategic Quality Management, Cengage Learning, Mason, $\mathrm{OH}$.

SPACE AND NAVAL WARFARE SYSTEMS CENTER (2005). Project management plan template. http://sepo.spawar.navy.mil/PMP Template.doc\# Toc9702 5400 [Accessed November 21, 2009].

THAMHAIN, H. J. (1994). Concurrent Engineering: Criteria for effective implementation. Industrial Management, 36(6), 29-29.

THOMAS, M., Jacques, P. H., Adams, J. R., KihnemanWooten, J. (2008). Developing an effective project: Planning and team building combined. Project Management Journal, 39(4), I05-II3.

WAGEMAN, R. (200I). How leaders foster self-managing team effectiveness: Design Choices versus hands-on coaching. Organization Science, 12(5), 559-577.

\section{About the Authors}

Angelo Pinheiro is a qualified Health, Environmental, and Safety (HES) professional with over 20 years experience in the upstream oil and gas industry. He earned a B.Tech. degree from Memorial University, Canada, and MS degree in Technology Management (safety management minor) from Texas A \& M University-Commerce, USA. He is currently enrolled in the $\mathrm{PhD}$ program in Fire and Emergency Management at Oklahoma State University, USA. Mr. Pinheiro is a member of the Society of Petroleum Engineers (SPE), American Society of Safety Engineers (ASSE), and Project Management Institute. He holds the Certified Safety Professional (CSP), Canadian Registered Safety Professional (CRSP), and Certified Professional Environmental Auditor (CPEA) certifications and currently works for an oil and gas exploration and production organization in Houston, TX, as Senior Health, Environmental, and Safety Professional. 